Discussion Paper No. 08-089

\title{
The Immigrant Wage Gap in Germany
}

Alisher Aldashev, Johannes Gernandt, and Stephan L. Thomsen

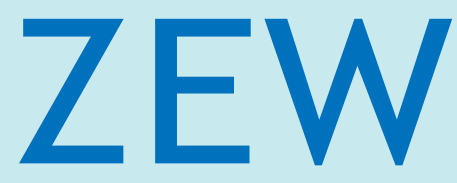

Zentrum für Europäische Wirtschaftsforschung $\mathrm{GmbH}$

Centre for European

Economic Research 
Discussion Paper No. 08-089

\title{
The Immigrant Wage Gap in Germany
}

\author{
Alisher Aldashev, Johannes Gernandt, \\ and Stephan L. Thomsen
}

Download this ZEW Discussion Paper from our ftp server:

ftp://ftp.zew.de/pub/zew-docs/dp/dp08089.pdf

Die Discussion Papers dienen einer möglichst schnellen Verbreitung von neueren Forschungsarbeiten des ZEW. Die Beiträge liegen in alleiniger Verantwortung der Autoren und stellen nicht notwendigerweise die Meinung des ZEW dar.

Discussion Papers are intended to make results of ZEW research promptly available to other economists in order to encourage discussion and suggestions for revisions. The authors are solely responsible for the contents which do not necessarily represent the opinion of the ZEW. 


\section{Non-technical summary}

Wage differentials between the native and immigrant population have been observed for many countries. The questions raised in the literature usually include identifying factors which cause the gap and whether the wages of the two groups converge. Human capital usually measured by years of formal education plays a central role. For example, imperfect transferability of human capital from the country of origin to the country of destination could lead to a wage differential between persons having the same formal qualification.

In Germany migration background has long been approximated by citizenship. Due to the fact that the share of naturalized immigrants has increased in the last years, this approximation seems to be quite imprecise. For example, in 2005 more than a half of persons with migration background possessed German nationality. However, one could make use of this heterogeneity of persons with migration background to analyze assimilation or integration of immigrants.

In this short study we analyze determinants of wage gap between foreigners, native Germans and naturalized immigrants using the data from the German Socio-Economic Panel (GSOEP). To analyze the effect of imperfect transferability of education degrees we compare wages of persons who received their degrees in Germany with those who received their degrees abroad across all migrant groups. The results clearly show the existence of the wage gap between foreigners and naturalized immigrants with respect to native Germans. The gap persists despite similarity in other characteristics like age, employment type, economic sector, place of residence or formal education. This enables us to conclude that citizenship does not automatically leads to assimilation or integration. On the other hand, the results imply imperfect transferability of human capital: the wage gap reduces dramatically if one compares only groups who completed their education in Germany. 


\section{Das Wichtigste in Kürze}

Die internationale empirische Literatur kann die Existenz von Lohndifferentialen zwischen Einheimischen und Immigranten für viele Länder bestätigen, wobei die Unterschiede zwischen den Ländern aber deutlich schwanken. Wichtige Fragen aus der Beobachtung betreffen zum einen die Bestimmung relevanter Erklärungsgrößen, zum anderen die mögliche Konvergenz. Eine zentrale Rolle für beide Aspekte spielt dabei das Humankapital bzw. die Messung über die formale Bildung. Insbesondere Unvollkommenheiten in der internationalen Übertragbarkeit des Humankapitals vom Heimat- auf das Gastland können bei formal gleicher Qualifikation zu beobachtbaren Lohnunterschieden führen.

In Deutschland wurde Immigration lange Zeit über die Staatsangehörigkeit abgebildet. Da der Anteil der Personen mit Migrationshintergrund und deutscher Staatsangehörigkeit in den letzten Jahren aber stetig zugenommen hat, greift diese Approximation zu kurz. So hatten im Jahr 2005 schon mehr als die Hälfte der Personen mit Migrationshintergrund die deutsche Staatsangehörigkeit. Aus methodischer Sicht kann die Trennung der Personen mit Migrationshintergrund über die Staatsangehörigkeit aber zum Vorteil gereichen, um die Effekte einer Assimilation bzw. Integration durch den Besitz der Staatsbürgerschaft zu analysieren.

In dieser kurzen Studie werden daher die Determinanten der Lohnunterschiede zwischen Ausländern und Deutschen sowie Personen mit Migrationshintergrund mit deutscher Staatsangehörigkeit und Deutschen separat analysiert. Die empirische Analyse basiert auf Daten des Sozioökonomischen Panels. Um den Effekt der unvollkommenen Transferierbarkeit von Bildungsabschlüssen offenzulegen, werden die Analysen für Personen, die ihre Abschlüsse in Deutschland erworben haben, mit beiden Migrantengruppen wiederholt. Die Ergebnisse machen deutlich, dass sowohl für Ausländer als auch für Personen mit Migrationshintergrund mit deutscher Staatsangehörigkeit deutliche Lohnunterschiede im Vergleich zur Referenzgruppe zu beobachten sind. Diese Unterschiede bestehen, obwohl die Personen in Merkmalen wie Alter, Beschäftigungsart, Industriezweig, Wohnort oder Ausbildung vergleichbar sind. Eine starke Assimilation bzw. Integration über die Staatsangehörigkeit ist daher nicht feststellbar. Die unvollkommene Transferierbarkeit des Humankapitals ist dagegen sehr deutlich: so reduzieren sich die Lohnunterschiede beider Migrantengruppen, wenn die Ausbildung in Deutschland erworben wurde. 


\title{
The Immigrant Wage Gap in Germany
}

\author{
Alisher Aldashev* \\ ZEW Mannheim \\ Johannes Gernandt ${ }^{\dagger}$ \\ ZEW Mannheim \\ Stephan L. Thomsen \\ OvG-University Magdeburg \& ZEW Mannheim
}

November 4, 2008

\begin{abstract}
Immigrants consist of foreigners and citizens with migration background. We analyze the wage gap between natives and these two groups in Germany. The estimates show a substantial gap for both groups with respect to natives. Discarding immigrants who completed education abroad reduces much of the immigrants' wage gap. This implies educational attainment in Germany is an important component of economic integration and degrees obtained abroad are valued less.
\end{abstract}

Keywords: Immigration, wage gap, decomposition, Germany

JEL Classification: J61, J31, J15

*Alisher Aldashev is Research Fellow at the Centre for European Economic Research (ZEW), L 7,1, D68161 Mannheim, e-mail: aldashev@zew.de.

$\dagger$ Johannes Gernandt is Research Fellow at the Centre for European Economic Research (ZEW), L 7,1, D-68161 Mannheim, e-mail: gernandt@zew.de.

${ }^{\ddagger}$ Stephan L. Thomsen (Corresponding Author) is Assistant Professor of Labor Economics at Otto-vonGuericke-University Magdeburg and Research Professor at ZEW, Mannheim. Address: Otto-von-GuerickeUniversity, Department of Economics and Management, PO Box 4120, D-39016 Magdeburg, e-mail: stephan.thomsen@ovgu.de, phone: +49 391 6718431, fax: +49 391 6711218. Stephan L. Thomsen acknowledges financial support from the Stifterverband für die Deutsche Wissenschaft (Claussen-Simon-Stiftung). 


\section{Introduction}

There is no doubt that immigrant-native wage differentials exist in many countries. Adsera and Chiswick (2007) show that differences in earnings of immigrants relative to natives of the same gender vary widely across countries, e.g., from about $19 \%$ (8\%) for men (women) in Germany to $67 \%$ (62\%) in Sweden. Observing these differentials has lead to a long discussion about explanations of the gap and a possible convergence (see, e.g., Chiswick, 1978, Borjas, 1994, and Altonji and Blank, 1999). Even formally equivalently educated immigrants may earn less due to a non-perfect international transferability of human capital and a less successful job matching of foreign-born workers (Chiswick and Miller, 2007). Similarly, Constant and Massey (2003) show that foreigners are not able to transfer their human capital into a good first job and, therefore, the status gap between Germans and foreigners widens over time. Moreover, the wage differential may partly be caused by the selection of immigrants in and out of the labor market. For example, Aldashev, Gernandt, and Thomsen (2007) show that language skills affect the labor market participation of foreigners.

It is important to differentiate between citizenship and migration background. For example in Germany, one fifth of the population have a migration background, whereas less than half of these people possess foreign citizenship in 2005 (about 47\%, Statistisches Bundesamt, 2007). Moreover, the number of German citizens with migration background has increased recently. Analyzing the wage gap for both groups separately could provide insights on the effects of assimilation and integration due to citizenship. Moreover, a further indicator of integration is educational attainment in the destination country.

We analyze the immigrants' wage gap in Germany providing explanations for the differences using a variant of the Oaxaca-Blinder-decomposition. Regarding foreigners and Germans with migration background separately, we study the wage gap for the latter group for the first time. To investigate how much of the wage gap between natives and immigrants is due to differences in the value of formally equivalently degrees obtained in the home and the destination country, we redo the decomposition for those who completed education in Germany only.

\section{Data and Descriptives}

Our empirical analysis is based on the wave of 2005 of the German Socio-Economic Panel (GSOEP). Started in 1984, GSOEP is a representative longitudinal study of almost 12,000 private households with more than 21,000 persons in Germany! To identify the migration

\footnotetext{
${ }^{1}$ See Haisken-DeNew and Frick (2005) for a detailed description.
} 
background, we use information on natives, foreigners, recent immigrants, and persons with German origin who immigrated from the (former) Soviet Union and Eastern European countries late after 1945. In addition, we are able to identify the parents of an individual if they took part in any of the waves. In these cases, we merge parental data with those of the individual. We define the three groups in analysis as follows: First, foreigners are all persons who possess a non-German citizenship in 2005. Second, Germans with migration background are naturalized immigrants and German resettlers who are Germans by law when immigrating. Finally, native Germans are all persons who did neither immigrate to Germany nor are children of immigrants.

For homogeneity reasons, we impose some restrictions on our sample. We only consider first generation immigrants, i.e. persons who immigrated themselves to Germany. The study is limited to West Germany for two reasons. The labor market situation differs in both parts and would necessitate separate estimations (unemployment rates in 2005: West Germany $11.0 \%$, East Germany 20.6\%). Unfortunately, the number of immigrants in East Germany is very small in our data. In addition, only employed persons aged 15 to 65 who report a wage are considered. The outcome variable (gross hourly wages) is obtained for all workers including the self-employed by dividing the gross wages in the month prior to the interview by the reported working hours of the last week that are extrapolated to monthly hours.

The final sample contains 3,035 (2,810) native German males (females), 365 (282) male (female) foreigners and 336 (315) German males (females) with migration background. Table 1 provides some descriptive statistics distinguished by gender. Starting with the gross hourly wage, natives earn on average more than both immigrant groups independently of gender. With respect to variables expecting to affect the wage, a few findings should be noted. Time of residence may affect individual's wage due to assimilation effects (Chiswick, 1978). Immigrants who reside in the destination country long enough may have a better command of the language and may be more accustomed to the country which in turn can affect productivity (see, e.g., Chiswick and Miller, 2007). The descriptives show that the time of residence of foreigners is longer on average than of Germans with migration background. The main reason may be that the latter group encompasses German resettlers who arrived in the late 1980s to early 1990s. Education is considered in three levels. People with school degree or without schooling are regarded as low-skilled, persons with professional training are medium-skilled, and those with college or university degree are the high-skilled. Taking a look at the average hourly wage for males shows that Germans with migration background earn less than foreigners despite having better education. This may indicate that naturalization does not necessarily lead to economic integration. 
Table 1: Means of selected characteristics

\begin{tabular}{|c|c|c|c|c|c|c|}
\hline & \multicolumn{3}{|c|}{ Males } & \multicolumn{3}{|c|}{ Females } \\
\hline & Natives & Foreigners & $\begin{array}{l}\text { Germans } \\
\text { with } \mathrm{MB}^{\mathrm{b}}\end{array}$ & Natives & Foreigners & $\begin{array}{l}\text { Germans } \\
\text { with } \mathrm{MB}^{\mathrm{b}}\end{array}$ \\
\hline Hourly wage & 16.23 & 14.52 & 13.65 & 12.76 & 10.30 & 10.82 \\
\hline Age & 41.98 & 40.61 & 38.77 & 41.16 & 40.30 & 38.96 \\
\hline Time of residence & - & 27.61 & 23.20 & - & 26.41 & 22.96 \\
\hline Part-time work & 0.04 & 0.07 & 0.07 & 0.42 & 0.40 & 0.38 \\
\hline Self-employed & 0.09 & 0.05 & 0.05 & 0.06 & 0.03 & 0.03 \\
\hline \multicolumn{7}{|l|}{ Education } \\
\hline Low & 0.12 & 0.35 & 0.23 & 0.14 & 0.49 & 0.29 \\
\hline Medium & 0.63 & 0.46 & 0.46 & 0.65 & 0.32 & 0.42 \\
\hline High & 0.25 & 0.19 & 0.31 & 0.20 & 0.18 & 0.29 \\
\hline \multicolumn{7}{|l|}{ Economic Sectors } \\
\hline Agriculture & 0.02 & 0.02 & 0.03 & 0.01 & 0.00 & 0.00 \\
\hline Industry & 0.32 & 0.52 & 0.56 & 0.14 & 0.27 & 0.19 \\
\hline Transportation & 0.08 & 0.07 & 0.07 & 0.05 & 0.04 & 0.05 \\
\hline Construction & 0.09 & 0.09 & 0.05 & 0.01 & 0.01 & 0.01 \\
\hline Trading services & 0.27 & 0.24 & 0.21 & 0.37 & 0.39 & 0.38 \\
\hline Social services and health & 0.22 & 0.06 & 0.09 & 0.42 & 0.29 & 0.37 \\
\hline \multicolumn{7}{|l|}{ Region $^{\mathbf{a}}$} \\
\hline North & 0.20 & 0.12 & 0.19 & 0.21 & 0.11 & 0.20 \\
\hline Center & 0.34 & 0.31 & 0.41 & 0.33 & 0.27 & 0.39 \\
\hline South & 0.46 & 0.56 & 0.40 & 0.45 & 0.61 & 0.41 \\
\hline No. of obs & 3,035 & 365 & 336 & 2,810 & 282 & 315 \\
\hline
\end{tabular}

\section{Methodology}

To quantify underlying causes of the wage differences between the natives and each of the two immigrants' groups, we apply a variant of the Blinder (1973)-Oaxaca (1973)decomposition technique suggested by Daymont and Andrisani (1984). The basic idea is that differences in wages could be explained by differences in characteristics (endowments) and by different returns to characteristics (coefficients) of groups. Daymont and Andrisani (1984) augment the decomposition equation by an interaction term capturing the perception of past discrimination (threefold-decomposition). Considering two arbitrary groups $A$ and $B$, the individual wage equation for each group is

$$
Y_{i j}=X_{i j} \beta_{j}+\varepsilon_{i j}, \quad j=A, B \text {. }
$$

$Y_{i j}$ is the $\log$ hourly wage of individual $i$ of group $j, X_{i j}$ is a vector of individual characteristics, $\beta_{j}$ is the vector of the corresponding coefficients for group $j$ and $\varepsilon_{i j}$ is the residual. 
The threefold decomposition is then

$$
\overline{\mathbf{Y}}^{A}-\overline{\mathbf{Y}}^{B}=\left(\overline{\mathbf{X}}^{A}-\overline{\mathbf{X}}^{B}\right) \boldsymbol{\beta}^{B}+\overline{\mathbf{X}}^{B}\left(\boldsymbol{\beta}^{A}-\boldsymbol{\beta}^{B}\right)+\left(\overline{\mathbf{X}}^{A}-\overline{\mathbf{X}}^{B}\right)\left(\boldsymbol{\beta}^{A}-\boldsymbol{\beta}^{B}\right),
$$

where the 'bar' denotes the sample averages. The first term on the right hand site captures differences in wages due to characteristics (endowment effect), the second term are differences in the coefficients (price effect). The last term is the interaction effect, i.e. a positive interaction effect implies that the returns of the group $A$ tend to be greater for those characteristics for which group $A$ has higher means and vice versa.

The covariates considered in the estimation are age, age squared, three skill levels, dummy variables for industry, dummy variables for part-time and self-employment and regional dummy variables. Moreover, interactions between the skill levels and age (and age squared) are considered. We also regard cohort effects.2 In addition, we include time of residence (and its square) in the wage equations of foreigners and Germans with migration background. Due to this, the wage equation of natives contains fewer covariates and we have to modify the decomposition slightly.

The wage equation of the native Germans (reference group) is given by

$$
\mathbf{Y}^{A}=\boldsymbol{\beta}_{0}^{A}+\mathbf{X}^{A} \boldsymbol{\beta}^{A}+\varepsilon^{A}
$$

where $\boldsymbol{\beta}_{0}$ denoting the coefficient of the constant and $\mathbf{X}$ are all covariates. For each of the immigrant groups, the wage equation is given by

$$
\mathbf{Y}^{B}=\boldsymbol{\beta}_{0}^{B}+\mathbf{X}^{B} \boldsymbol{\beta}^{B}+\mathbf{Z} \boldsymbol{\gamma}+\boldsymbol{\varepsilon}^{B}
$$

with $\mathbf{Z}$ denoting time of residence and its square and $\gamma$ as the corresponding vector of coefficients. Using the estimated coefficients $\hat{\boldsymbol{\beta}}^{B}$, we estimate

$$
\mathbf{Y}^{B}=\boldsymbol{\delta}_{0}+\mathbf{X}^{B} \boldsymbol{\beta}^{B}+\boldsymbol{\zeta}, \text { s.t. } \boldsymbol{\beta}^{B}=\hat{\boldsymbol{\beta}}^{B}
$$

Since

$$
E\left(\mathbf{Y}^{B}\right)=\hat{\boldsymbol{\beta}}_{0}^{B}+\overline{\mathbf{X}}^{B} \hat{\boldsymbol{\beta}}^{B}+\overline{\mathbf{Z}} \hat{\boldsymbol{\gamma}}=\hat{\boldsymbol{\delta}}_{0}+\overline{\mathbf{X}}^{B} \hat{\boldsymbol{\beta}}^{B},
$$

the constant term $\boldsymbol{\delta}_{0}$ in eq. 5 captures the effect of average time of residence (and its square) on wages. As a result, in the decomposition the endowment effect would capture the differences in the covariates excluding time of residence and time of residence (squared), and the average effect of these variables is included in the price effect.

\footnotetext{
${ }^{2}$ See Borjas (1994) on the relevance of cohort effects. We distinguish four birth cohorts: born before 1950, 1950-59, 1960-69, and after 1970.
} 


\section{Results}

The coefficient estimates from the wage equations are in line with expectations and are not presented here $3^{3}$ Results from the decomposition of the wage gap between foreigners and natives and between Germans with migration background and natives are given in the upper panel of Table 2. The predicted wage gap between foreigners and natives is quite substantial with $11.3 \%$ (men) to $20.0 \%$ (women). Only half of the gap (49\%) for men can be explained by differences in endowments. If we assume unobserved productivity differences between both groups to be zero, the remaining $51 \%$ of the gap (5.8\% of wage) could be interpreted as an upper bound estimate of discrimination. Differences in endowments do not explain the wage gap of foreign women; here, the unexplained component accounts for about $88 \%$ of the gap. The results for Germans with migration background show a substantial wage gap of $16.5 \%$ (men) and $14.8 \%$ (women) with natives, too. For these groups, the unexplained part of the gap is even higher.

Table 2: Decomposition of log real gross hourly wages

\begin{tabular}{|c|c|c|c|c|}
\hline & \multicolumn{2}{|c|}{ Foreigners } & \multicolumn{2}{|c|}{$\begin{array}{c}\text { Germans with } \\
\text { migration } \\
\text { background }\end{array}$} \\
\hline & Males & Females & Males & Females \\
\hline \multicolumn{5}{|l|}{ Full Sample } \\
\hline Predicted difference & $0.113 * * *$ & $0.200 * * *$ & $0.165^{* * *}$ & $0.148 * * *$ \\
\hline Endowment effect & $\begin{array}{l}0.056^{* * * *} \\
(49 \%)\end{array}$ & $\begin{array}{l}0.023 \\
(12 \%)\end{array}$ & $\begin{array}{l}0.021 \\
(13 \%)\end{array}$ & $\begin{array}{l}0.057 * * * \\
(39 \%)\end{array}$ \\
\hline Price effect & $\begin{array}{l}0.065^{* * * *} \\
(57 \%)\end{array}$ & $\begin{array}{l}0.145^{* * * *} \\
(73 \%)\end{array}$ & $\begin{array}{l}0.137 * * * \\
(83 \%)\end{array}$ & $\begin{array}{l}0.119 * * * \\
(80 \%)\end{array}$ \\
\hline Interaction effect & $\begin{array}{l}-0.007 \\
(-6 \%)\end{array}$ & $\begin{array}{l}0.031^{* *} \\
(16 \%)\end{array}$ & $\begin{array}{r}0.006 \\
(4 \%)\end{array}$ & $\begin{array}{l}-0.028 * * \\
(-19 \%)\end{array}$ \\
\hline \multicolumn{5}{|c|}{ Education in Germany } \\
\hline Predicted difference & 0.022 & $0.124 * * *$ & $0.091 * * *$ & $0.100 * *$ \\
\hline Endowment effect & $\begin{array}{r}0.028 \\
(127 \%)\end{array}$ & $\begin{array}{l}0.085^{* * * *} \\
(68 \%)\end{array}$ & $\begin{array}{l}-0.039 * * \\
(-42 \%)\end{array}$ & $\begin{array}{l}0.050 * \\
(50 \%)\end{array}$ \\
\hline Price effect & $\begin{array}{r}0.054 \\
(243 \%)\end{array}$ & $\begin{array}{l}0.110^{* * * *} \\
(89 \%)\end{array}$ & $\begin{array}{l}0.095^{* * *} \\
(104 \%)\end{array}$ & $\begin{array}{l}0.073 * * \\
(73 \%)\end{array}$ \\
\hline Interaction effect & $\begin{array}{l}-0.060 * * * \\
(-270 \%)\end{array}$ & $\begin{array}{l}-0.071^{* * *} \\
(-57 \%)\end{array}$ & $\begin{array}{l}0.035^{* *} \\
(38 \%)\end{array}$ & $\begin{array}{l}-0.023 \\
(-23 \%)\end{array}$ \\
\hline
\end{tabular}

These results clearly indicate that immigrants are paid less than natives for observationally equivalent characteristics irrespective of citizenship. Besides discrimination, one reason may be that observationally equivalent educational degrees attained in different countries are not necessarily comparable. Even if contents of education may be comparable, skills

\footnotetext{
${ }^{3}$ Results are available on request from the authors.
} 
acquired may be not applicable in the destination country for different reasons, e.g. a lack of demand or differences in technology. Thus, immigrants may be less able than the natives to transfer their human capital into Germany's labor market. To analyze the value of educational attainment we redo the analysis regarding only persons who completed their education in Germany (lower panel of Table 2). The results show a significant drop in the wage gap for foreigners by about 8 percentage points. The coefficient effect is smaller as well implying skills acquired abroad are valued less, but the difference is almost compensated by the negative interaction effect. The interpretation of the interaction effect is that because foreign men tend to have the characteristics for which they are better paid the gap is reduced by 6 percentage points. For Germans with migration background the predicted wage gap drops, too. In this group, the negative endowment effect for males should be noted. Hence, this group would have earned more than the natives had the remuneration been the same.

\section{Conclusion}

This study shows that there is a considerable wage gap between immigrants and natives in Germany. Much of the gap is due to the fact that immigrants are paid less than natives for observationally equivalent characteristics. Wage gaps of foreigners and nationals with migration background with respect to natives do not differ much. Thus, economic integration of immigrants does not depend on citizenship. Discarding persons who completed education abroad reduces the wage gap substantially. Educational attainment in Germany is therefore an important component of economic integration and degrees obtained abroad are valued less. However, even accounting for education completed in Germany still leaves a significant unexplained part of the wage gap.

\section{References}

Adsera, A., And B. Chiswick (2007): "Are there Gender and Country of Origin Differences in Immigrant Labor Market Outcomes across European Destinations?," Journal of Population Economics, 20, 495-526.

Aldashev, A., J. Gernandt, and S. L. Thomsen (2007): "Language Usage, Participation, Employment and Earnings," FEMM Discussion Paper No. 07-18, University of Magdeburg. 
Altonji, J. G., And R. M. Blank (1999): "Race and Gender in the Labor Market," in Handbook of Labor Economics, ed. by O. Ashenfelter, and D. Card, vol. 3C, chap. 48, pp. 3143-3259. Elsevier Science B.V., Amsterdam.

BLINDER, A. S. (1973): "Wage Discrimination: Reduced Form and Structural Variables," Journal of Human Resources, 8, 436-455.

BORJAS, G. J. (1994): “The Economics of Immigration,” Journal of Economic Literature, $32,1667-1717$.

CHISWICK, B. R. (1978): “The Effect of Americanization on the Earnings of Foreign-born Men," Journal of Political Economy, 86(5), 897-921.

Chiswick, B. R., AND P. W. MiLler (2007): “The International Transferability of Immigrants' Human Capital,” Discussion Paper No. 2670, IZA.

Constant, A., And D. S. MASsey (2003): "Labor Market Segmentation and the Earnings of German Guestworkers,” Discussion Paper No. 774, IZA.

DAYMont, T. N., And P. J. ANdRisAni (1984): “Job Preferences, College Major, and the Gender Gap in Earnings," The Journal of Human Resources, 19(3), 408-428.

HAISKEN-DeNeW, J., AND J. FRICK (2005): "Desktop Companion of the German SocioEconomic Panel," Companion, DIW, Berlin.

OAXACA, R. (1973): “Male-Female Wage Differentials in Urban Labor Markets," International Economic Review, 14, 693-708.

Statistisches Bundesamt (2007): Bevölkerung mit Migrationshintergrund - Ergebnisse des Mikrozensus 2005. Statistisches Bundesamt, Wiesbaden. 